УДК 378.011.3-051:51

DOI:

Роман Бобовський, стариий викладач кафедри математики, інформатики та методики навчання Переяслав-Хмельницького державного педагогічного університету імені Григорія Сковороди

\title{
СТРУКТУРОЛОГІЧНИЙ АНАЛІЗ ФЕНОМЕНА “ПЕДАГОГІЧНА СВІДОМІСТЬ МАЙБУТНЬОГО ВЧИТЕЛЯ МАТЕМАТИКИ"
}

У статті здійснено теоретичний аналіз теоретико-методологічних підходів до вивчення феномену педагогічної свідомості. На основі аналізу наукових прачь було визначено структурні компоненти педагогічноі свідомості майбутнього вчителя математики (мотиваційно-ціннісний, інтелектуально-пізнавальний, операційно-діяльнісний та рефлексивний компоненти).

Ключові слова: формування педагогічної свідомості; структура педагогічної свідомості; компоненти педагогічної свідомості; педагогічна свідомість.

Jim. 13.

Roman Bobovskiy, Senior Lecturer of the Mathematics, Informatics and Teaching Methods Department Pereyaslav-Khmelnytskiy Hryhoriy Skovoroda State Pedagogical University

\section{STRUCTURALANALYSIS OF PHENOMENON "PEDAGOGICAL CONSCIOUSNESS OF FUTURE TEACHER OFMATHEMATICS"}

The article deals with the theoretical and methodological approaches, the theoretical analysis of the study of the pedagogical consciousness phenomenon. The article deals with the research of scientists who considered the theoretical and methodological aspects of professional consciousness and self-awareness (O. Hrinov, V. Demichev, I. Donchenko, N. Krytska, K. Markov, E. Matviyevska, M. Mitin, L. Rymar, V. Koziyev, N. Shevchenko, etc.), problems of the content, structure and functions of pedagogical consciousness (B. Bratus, E. Isayev, S. Kosaretskiy, S. Rubinstein, E. Yudina, etc.), the process of forming the integrity of pedagogical consciousness (S. Dnyeprov, S. Kuznetsova, L. Pleskach, V. Slobodchykov, N. Sidash, A. Tsokur, A. Fomin etc.). On the basis of the scientific analysis of works, the structural components of pedagogical consciousness of future teacher of mathematics (motivational-value, intellectual-cognitive, operational-activity and reflexive components) were determined. The motivational-value component is characterized by the domination of professional motives of the future teacher of mathematics. The intellectual-cognitive component contributes to the conscious assimilation of the vocational and pedagogical knowledge, skills and abilities that are totality components of pedagogical competence. The operational-activity component characterizes the pedagogical activity in terms of formation of the professional and pedagogical skills and abilities of future teacher. The reflexive component of pedagogical consciousness of future teacher of mathematics characterizes the cognition and analysis by the teacher of the phenomena of his own activities. Thus, the allocation of characteristic indicators of each component will enable to find effective methods for the determining of formation of the pedagogical consciousness of future teacher of mathematics according to each indicator and determine the levels of formation of pedagogical consciousness of future teachers of mathematics.

Keywords: formation of pedagogical consciousness; a structure of pedagogical consciousness; the components of pedagogical consciousness; pedagogical consciousness.

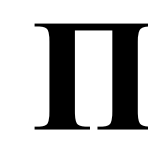

остановка прблеми. Дослідження закономірностей становлення та розвитку професійної свідомості студентів різних спеціальностей є окремим напрямком дослідження в психології та педагогіці вищої школи. У представників різних професій на етапі навчання в університеті повинна формуватись відмінна від інших притаманна тільки їм професійна свідомість [13, 286].

Мета статті полягає у теоретичному аналізі та обгрунтуванні структурних компонентів педагогічної свідомості майбутніх вчителів математики.

Аналіз основних досліджень. На сьогодні проблема формування, становлення та розвитоку педагогічної свідомості та якісної підготовки майбутніх учителів була розглянута різними науковцями. Найбільш важливими для нашого дослідження є праці вчених, які розглядали теоретичні та методологічні аспекти професійної свідомості та самосвідомості (О. Гріньова, В. Демічев, І. Донченко, Н. Крицька, К. Маркова, Є. Матвієвська, М. Мітіна, Л. Римар, В. Козієв, Н. Шевченко та ін.), проблеми змісту, структури та функцій педагогічної свідомості (Б. Братусь, С. Ісаєв, С. Косарецький, С. Рубінштейн, С. Юдіна та ін.), процес формування цілістності педагогічної свідомості (С. Днєпров, С. Кузнецова, Л. Плескач, В. Слободчиков, Н. Сідаш, О. Цокур, А. Фомін та ін.). 
Виклад основного матеріалу. Водночас дослідники не одностайні у визначенні структури досліджуваного явища, а отже, і в діагностиці їі компонентів. Щодо проблеми формування педагогічної свідомості майбутнього вчителя математики, зокрема аналізу та діагностики їі структурних компонентів, то вона й досі залишається поза увагою дослідників, що й зумовило вибір дослідження.

Перш за все, зазначимо, що у нашому дослідженні педагогічна свідомість майбутнього вчителя математики являє собою інтегративне утворення особистості, що характеризується усвідомленням сукупності педагогічних ідей, теорій, поглядів, цінностей, норм поведінки реалізованих у власній педагогічній діяльності та здатністю до рефлексії.

Педагогічна свідомість спрямовується на аналіз різних сторін “ $Я$ ” особистості вчителя і його педагогічної діяльності та визначення перспектив особистісного сенсу. За допомогою чого вчитель має можливість самовизначатися i самореалізовуватися. Будучи не тільки системою найбільш загальних суджень, знань про діяльність, про себе, про інших і суспільство, педагогічна свідомість $є$ одночасно продуктом і результатом виключно індивідуального досвіду, особливим механізмом професійного становлення особистості вчителя.

Спираючись на визначення сутності, на основі системного підходу вибудуємо структуру поняття “педагогічна свідомість” майбутнього учителя математики, що дозволить нам розробити критерії іï оцінки.

Відповідно до теоретичних засад системного підходу зауважимо, що дослідження процесу формування педагогічної свідомості як психологопедагогічного явища орієнтує дослідника на розкриття цілісності об'єкта, виявлення різнорівневих зв'язків, як внутрішніх, так і зовнішніх, зведення та узагальнення всіх знань про об'єкт, що досліджується.

Відомий психолог К. Платонов, визначаючи поняття структури, зазначає, що структура залишається незмінною, незважаючи на постійну зміну частин і самого цілого, і змінюється лише тоді, коли все ціле переживає якісний стрибок [7, 127].

У філософській довідковій літературі термін “структура" визначається як “спосіб закономірного зв’ язку між складовими предметів і явищ природи та суспільства, мислення та пізнання, сукупність істотних зв'язків між виділеними частинами цілого, що забезпечує його єдність" [9, 611].

Таким чином, виявлення процесуальних особливостей розвитку педагогічної свідомості майбутнього учителя математики на даному етапі дослідження забезпечується описанням структури даного інтегративного утворення.

Тож, проаналізуємо підходи деяких науковців до визначення структурних компонентів досліджуваного феномену. Зауважимо, що у педагогічній літературі дослідження останнього проводилися у різних аспектах. Деякими науковцями розглядалися терміни “педагогічна самосвідомість”, “професійна свідомість”, “професійна самосвідомість”, іншими педагогічна свідомість представників інших професій. Розглянемо різні варіанти виокремлення структурних компонентів у близьких за змістом до досліджуваного феномену термінів.

Так, Н. Шевченко, досліджуючи професійну свідомість практичного психолога, зауважувала, що даний феномен містить у собі професійну освіченість, професійну культуру діяльності, а також мисленнєву діяльність яка сягає методологічної рефлексії. У роботі науковця представлена трикомпонентна структура професійної свідомості, яка відображає специфіку професії: значення, які виражаються психологічними поняттями й категоріями; смисли, які мають своє втілення у інтересах, мотивах та цілях діяльності практичного психолога; чуттєві переживання, які характеризуються особливістю сприйняття реальності у професійній взаємодії “клієнт - психолог” [12].

Структуру професійної самосвідомості майбутнього вчителя-психолога досліджувала i Гріньова О., виокремлюючи у ній “Я-ідеальне", тобто наявний у студентів ідеал майбутнього вчителя-психолога, “Я-реальне”, тобто сукупність уявлень студентів про себе в якості майбутнього фахівця і самооцінку, яка відображає розбіжності між “Я-ідеальним” та “Я-реальним” компонентами їх професійної самосвідомості [1]

Значущою для нашого дослідження є і позиція Н. Шварп, у роботі якого представлено структуру професійної самосвідомості працівників фармацевтичної галузі. Ї̈̈ автор уявляє як єдність мотиваційного, когнітивного, афективного й практичного компонентів.

Так, мотиваційний компонент професійної самосвідомості майбутніх фармацевтів і провізорів включає професійну мотивацію (професійний інтерес; бажання надавати людям медичну допомогу; прагнення до оволодіння новою інформацією, до реалізації професійноособистісної самоактуалізації з урахуванням вимог до сучасного фармацевтичного фахівця; усвідомлення значущості особистісних якостей 


\section{СТРУКТУРОЛОГІЧНИЙ АНАЛІЗФЕНОМЕНА "ПЕДАГОГІЧНАСВІДОМІСТЬ МАЙБУТНЬОГО ВЧИТЕЛЯ МАТЕМАТИКИ"}

(чесність, відповідальність, тактовність, комунікабельність). Когнітивний компонент професійної самосвідомості передбачає наявність у студентів знань про призначення, роль і місце професії фармацевта в сучасному суспільстві, про необхідні фахівцю знання з питань надання населенню фармацевтичних послуг, забезпечення гарантій якості та безпеки застосування лікарських засобів і медичної продукції тощо. Афективний компонент включає самоповагу, прагнення особистості до формування адекватного самосприйняття й ставлення до себе як професіонала, уміння правильно визначати й аналізувати власні емоції з приводу наявних успіхів і невдач, а також використовувати систему власних емоційних сигналів для подальшого професійно-особистісного становлення та поліпшення стосунків із членами колективу й іншими людьми [11].

Останній із визначених компонентів практичний - передбачає сформованість в особистості таких груп умінь: 1) комунікативних (уміння швидко налагоджувати контакт із людьми, організовувати передачу й сприйняття інформації, проявляти емпатію, запобігати виникненню конфліктів, а в разі виникнення - обирати ефективну стратегію їх розв'язання); 2) самоорганізації (уміння визначити мету майбутньої діяльності, розробляти план ii досягнення, продукувати рішення професійних проблем, обирати способи дій і послідовно їх реалізовувати в діяльності), 3) самоконтролю (уміння усвідомлено контролювати свої дії, психічні процеси та стани, визначати проміжні й остаточні результати своєї діяльності, розбіжності між “Я-реальним" і “Я-ідеальним" тощо); 4 ) саморегуляиії (уміння керувати своїми емоціями, психічними станами, діями, за необхідності змінюючи їх шляхом прояву вольових зусиль, уміння релаксації тощо); 5) рефлексивних (уміння здійснювати самопізнання внутрішніх психічних проявів і станів, самоаналіз, самовизначення в практичних ситуаціях, зіставляти свою поведінку з діями інших людей тощо); 6) професійного самовиховання (уміння визначати свої особистісні якості, які сприяють успішній професійній діяльності чи, навпаки, заважають їй, складати програму професійного самовдосконалення, реалізовувати її на практиці, використовуючи різні методи самовиховання, тощо) [11].

У свою чергу, І. Донченко досліджувала категорію “професійна самосвідомість викладача ВНЗ” і виділяла уній такі компоненти: професійна Я-концепція як динамічна сукупність образів Я, у яких відображено уявлення викладача про себе як суб’єкта професійної діяльності (“Я-реальнеособистісне”, “Я-професійне-дієве”, “Япрофесійне-нормативне”); професійна самоорганізація як особливий психологічний феномен, сугність якого полягає у прагненні фахівця до постійного професійного саморозвитку, професійного самовдосконалення та самозбереження в ситуації мінливості професійного простору, що $є$ механізмом формування та розвитку професійної Я-концепції, а також засобом реалізації Я-концепції у професійній діяльності, виявляється в сукупності процесів самопідготовки (самопізнання й саморозвиток) та самореалізації (самовираження й самоствердження); професійна рефлексія як здатність до самоаналізу власного Я, власної професійної діяльності; механізм усвідомлення взаємозв' язків між професійною Я-концепцією та професійною самоорганізацією, завдяки якому внутрішнє, суб'єктивне (професійна Я-концепція) i зовнішнє, об'єктивне (професійна самоорганізація) поєднуються в єдине цілісне явище [2].

Вихідним теоретичним положенням виділення структурних компонентів педагогічної самосвідомості майбутнього вчителя у роботі Л. Римар стало розуміння їх як єдності пізнавального (самопізнання), емоційно-ціннісного (самооцінка), дієво-вольового, регулятивного (саморегуляція) аспектів. В результаті автор виокремив такі компоненти педагогічної самосвідомості: 1) професійна установка на педагогічну діяльність; 2) наявність потреби в самопізнанні (які якості особистості майбутній учитель усвідомлює як необхідні і констатує їх наявність у себе); 3) самооцінка професійно значущих якостей; 4) саморегуляція у розв'язанні педагогічних задач; 5) відповідні мотиви професійного самовдосконалення [8].

Когнітивним, афективним і поведінковим компонентами представлена "професійна самосвідомість” педагога у роботі Є. Матвієвської. Когнітивний компонент, який на думку автора, є провідним у структурі професійної самосвідомості, включає процес самопізнання і його результат систему знань про себе, свою діяльність. Афективний компонент являє собою сукупність трьох видів відносин, які інтерпретуються в контексті формування культури оціночної діяльності педагога наступними відносинами: 1) відношенням до здійснюваної оціночної діяльності, коли їі логіка змінюється з традиційної на рефлексивну, до педагогічних дій, обраних засобів і способів досягнення мети; 2) ставленням до здійснюваної в ході оціночної діяльності 
взаємодії з учнями; емоційною оцінкою того, як педагог реалізує суб'єктну взаємодію, функції культури оціночної діяльності; 3) ставленням до своїх професійно значущих якостей, що дозволяють (або не дозволяють) здійснювати гуманістичну взаємодію педагога і учня при збереженні їх суб' єктності в даному процесі як вищої цінності; в цілому до своєї особистості педагога-професіонала; характеризується оцінкою відповідності професійної компетентності власне ідеального образу “Я-педагога". Поведінковий компонент професійної самосвідомості педагога детермінують його знання про особистісні та професійні якості, адекватну оцінку своєї поведінки, уміння вибудовувати гуманістичну взаємодію з учнями в процесі оціночної діяльності, а також самооцінка емоційно-ціннісного ставлення до себе, яка виникає на основі цих знань [5].

А. Маркова [4] та Л. Мітіна [6] у структурі професійноі самосвідомості майбутнього вчителя виділяють когнітивний, емоційний і поведінковий компоненти. Когнітивний компонент, на думку авторів, представляє процес самопізнання і його результат - систему знань вчителя про себе як фахівця. Афективний компонент характеризується як сукупність трьох видів ставлень: до системи своїх педагогічних дій, своїх цілей і завдань, способів досягнення цих цілей, результатів своєї праці; до системи міжособистісних взаємин 3 учнями, реалізації основних функцій педагогічного спілкування, а саме: інформаційної, соціальноперцептивної, презентативної, інтерактивної, афективної; до своїх професійно значущих якостей і власної особистості як професіонала в цілому. Поведінковий компонент професійної самосвідомості майбутнього учителя, як доводять автори, характеризується діяльнісними проявами, оскільки основним психологічним механізмом цієї підструктури є задоволеність педагога собою i власною професійною діяльністю.

На думку В. Козієва, основною складовою професійної самосвідомості вчителя є оцінка ним власних професійних якостей, досягнень, визначення напрямків саморозвитку [3]. Відтак, структура професійної самосвідомості майбутнього вчителя, розроблена автором, включає наступні компоненти: самоставлення i самооцінка вчителя (актуальне “Я”); самооцінка вчителем попередніх етапів професійного становлення (ретроспективне “Я”); професійний ідеал учителя (ідеальне “Я”); те, як на думку вчителя, його сприймають знайомі і колеги (ретроспективне “Я”).
О. Цокур, досліджуючи структуру педагогічної свідомості, дійшла до висновку, що механізм іiі функціонування заснований на взаємовідносинах суб'єкта і об'єкта педагогічної діяльності, що реалізуються в процесі практики виховання i освіти, а внутрішня структура обумовлюється єдністю і взаємодією трьох основних сфер (предметно-змістовної, операційно-технологічної і рефлексивно-оціночної) [10].

Перша сфера педагогічної свідомості вчителя - предметно-змістовна сфокусована, як зауважує науковець, в основному, на відображенні особливостей життєдіяльності учня як об'єкта його професійної діяльності. Системоугворюючими функціями даної сфери педагогічної свідомості $\epsilon$ пізнавальна, орієнтовна і діагностична. За їх допомогою вчитель сприймає і інтерпретує особливості внутрішнього духовного світу учня, складає “педагогічний портрет" реальної дійсності, який в найбільш досконалому вигляді проявляється в діяльності вчителя на етапі аналізу ним реальних ситуацій навчальновиховного процесу [10].

Друга сфера педагогічної свідомості операційно-технологічна грунтується на основі функціонування системи уявлень учителя про способи і засоби організації навчально-виховного процесу в єдності двох його складових: навчально-виховної діяльності учня і педагогічної діяльності вчителя. Системо-утворюючими функціями даної сфери педагогічної свідомості є пізнавальна, проектувальна та конструктивна, реалізуючи які, учитель стає здатним трансформувати зміст професійної мети в операційно-діяльнісну форму, яка відображує логіку педагогічних дій в конкретних ситуаціях навчально-виховного процесу. Зміст операційнотехнологічної сфери педагогічної свідомості заснований на інформації, що дозволяє вчителю конкретизувати загально-логічні форми і методи наукового пізнання і моделювання щодо дослідження сутності взаємозв'язку компонентів навчально-виховного процесу [10].

Рефлексивно-оцінна сфера педагогічної свідомості регулює блок інформації, що відображає уявлення вчителя про самого себе як професіонала. Системоутворюючими функціями даної сфери є пізнавальна, критеріально-цільова і контрольно-коригуюча функції, з допомогою яких вчителю надається можливість передбачати найбільш характерні властивості та особливості кінцевого продукту своєї професійної діяльності за допомогою обліку своїх реальних і потенційних можливостей. Найбільш яскраво функціонування рефлексійно-оціночної сфери педагогічної 


\section{СТРУКТУРОЛОГІЧНИЙ АНАЛІЗ ФЕНОМЕНА “ПЕДАГОГІЧНАСВІДОМІСТЬ МАЙБУТНЬОГО ВЧИТЕЛЯ МАТЕМАТИКИ"}

свідомості виявляється в діяльності вчителя на етапі самоаналізу ним якості власної педагогічної діяльності з реалізації прийнятих ним рішень [10].

Таким чином, узагальнюючи проаналізовані вище підходи науковців до розуміння структури педагогічної свідомості і суміжних з нею понять, беручи до уваги специфіку професійної діяльності вчителя математики, ми виокремлюємо мотиваційно-ціннісний, інтелектуальнопізнавальний, операційно-діяльнісний та рефлексивний компоненти педагогічної свідомості.

Узагальнюючи зазначене, можна зробити висновок про те, що дослідження сутності характерних показників кожного компонента дасть змогу підібрати ефективні методики для 3'ясування сформованості педагогічної свідомості майбутнього вчителя математики за кожним показником та визначити рівні сформованості педагогічної свідомості майбутніх вчителів математики.

\section{ЛІТЕРАТУРА}

1. Гріньова О. М. Психологічні особливості професійного самовизначення майбутніх учителів в умовах підготовки за двома спеціальностями: автореф. дис. канд. психол. наук: 19.00.07 / O.М. Гріньова; Нац. пед. ун-т ім. Н.П. Драгоманова. - К., 2008. - 20 с.

2. Донченко I. А. Педагогічні умови розвитку професійної самосвідомості майбутніх викладачів вищого навчального закладу в процесі магістерської підготовки: автореф. дис. на здоб. наук. ступеня канд. пед. наук: спец. 13.00.04 теор. і метод. проф. осв. / I.А. Донченко; Класичний приватний університет. - Запоріжжя:, 2010. - 25 с.

3. Козиев В.Н. Формирование профессиональных качеств личности учителя / Козиев В.Н. / Автореф. дисс. ... канд. психол. наук. - Л., 1980. - 21 с.

4. Маркова А.К. Психология профессионализма / Маркова А.К. - М.: Междунар. гуманит. фонд “Знание”, 1996. - 312 с.

5. Матвиевская Е. Г. Профессиональное самосознание педагога как основа формирования культуры оценочной деятельности в системе повышения квалификации // Теория и практика образования в современном мире: материалы Междунар. науч. конф. (г. Санкт-Петербург, февраль 2012 г.). - СПб.: Реноме, 2012. - С. 392396. - URL https://moluch.ru/conf/ped/archive/21/ $1808 /$

6. Митина Л. М. Психология профессионального развития учителя / Митина Л.М. - М.: Флинта, 1998. - $156 \mathrm{c}$.
7. Платонов К.К. Структура и развитие личности: психология личности / К.К. Платонов, А.Д. Глоточкин. - Москва: Наука, 1986. - 256 с.

8. Римар Л. В. Формування професійної самосвідомості майбутніх учителів у процесі вивчення педагогічних дисциплін Автореф. дис. канд. пед. наук: 13.00.01 / Л.В. Римар; Нац. пед. ун-т ім. Н.П. Драгоманова. - К., 1999. - 22 с.

9. Філософський енциклопедичний словник / В.І. Шинкарук, Л.В. Озадовська, Н. П. Поліщук; I.О. Покаржевська. - Київ: Абрис, 2002. - 742 с.

10. Цокур О.С. Категория педагогического сознания в теории и практике профессиональной подготовки учителя: дис. доктора пед. наук: 13.00.01; 13.00.04 / О.С. Цокур. -1998. - 269 с.

11. Шварп Н.В. Формування професійної самосвідомості студентів фармацевтичного університету у процесі фахової підготовки: автореф. дис. на здоб. наук. ступеня канд. пед. наук: спец. 13.00 .04 - теор. і метод. проф. осв. / Н.В. Шварп; ХНПУ ім. Г.С. Сковороди. - Харків: 2011. - 19 c.

12. Шевченко Н.Ф. Формування професійної свідомості практичних психологів у системі вищої освіти Автореф. дис. д-ра психол. наук: 19.00.07 / Н.Ф. Шевченко; Ін-т психології ім. Г.С. Костюка АПН України. - К., 2006. - 32 с.

13. Bobovsky R.P. Model structural components of pedagogical consciousness formation in future math teacher / R.P. Bobovsky // Geopolitical processes in the world today: Collection of scientific articles. "East West" Association for Advanced Studies and Higher Education. Vienna (Austria). 2016. - P. 286 -289 .

\section{REFERENCES}

1. Grinova, O. M. (2008). Psykholohichni osoblyvosti profesiinoho samovyznachennia maibutnikh uchyteliv v umovakh pidhotovky za dvoma spetsialnostiamy [Psychological peculiarities of professional self-determination of future teachers in preparation for two specialties]. Extended abstract of candidate's thesis. Kyiv: Nats. ped. un-t im. N.P. Drahomanova, 20 p. [in Ukrainian].

2. Donchenko, I. A. (2010). Pedahohichni umovy rozvytku profesiinoi samosvidomosti maibutnikh vykladachiv vyshchoho navchalnoho zakladu v protsesi mahisterskoi pidhotovky [Pedagogical conditions of development of professional selfknowledge of future teachers of higher educational institutions in the process of master's training]. Extended abstract of candidate's thesis. Zaporizhzhia: Klasychnyi pryvatnyi universytet, 25 p. [in Ukrainian].

3. Koziev, V. N. (1980). Formirovanie 


\section{СТРУКТУРОЛОГІЧНИЙ АНАЛІЗФЕНОМЕНА

professionalnykh kachestv lichnosti uchitelya [Formation of professional qualities of the teacher's personality]. Extended abstract of candidate's thesis. Lviv, 21 p. [in Russian].

4. Markova, A. K. (1996). Psykholohyia professyonalyzma [Psychology of professionalism]. Moskva: Mezhdunar. humanyt. fond "Znanye", 312 p. [in Ukrainian].

5. Matvievskaya, E. G. (2012). Professionalnoe samosoznanie pedagoga kak osnova formirovaniya kultury otsenochnoy deyatelnosti $\mathrm{v}$ sisteme povysheniya kvalifikatsii [Professional self-awareness of the teacher as the basis for the formation of a culture of evaluation activities in the system of professional development]. Teoriya i praktika obrazovaniya $v$ sovremennom mire: materialy Mezhdunar. nauch. konf. (g. Sankt-Peterburg, fevral 2012 g.). - The theory and practice of education in in the modern world: the materials of International scientific conference. (St. Petersburg, February 2012). (pp. 392-396). St.Petersburg: Renome, available at: https://moluch.ru/conf/ped/ archive/21/1808/ [in Russian].

6. Mitina, L. M. (1998). Psikhologiya professionalnogo razvitiya uchitelya [Psychology of professional development of the teacher]. Moskva: Flynta, 156 p.[in Russian].

7. Platonov, K. K. \& Glotochkin, A. D. (1986). Struktura $i$ razvitie lichnosti: psikhologiya lichnosti [Structure and development of the personality: personality psychology]. Moskva: Nauka, $256 \mathrm{p}$.

8. Rymar, L.V. (1999). Formuvannia profesiinoi samosvidomosti maibutnikh uchyteliv u protsesi vyvchennia pedahohichnykh dystsyplin [Formation of professional self-consciousness of future teachers in the process of studying pedagogical disciplines]. Extended abstract of candidate's thesis. Kyiv: Nats. ped. un-t im. N.P. Drahomanova, 22 p. [in Ukrainian].

9. Shynkaruk, V. I., Ozadovska, L.V., Polishchuk, N. P. \& Pokarzhevska, I.O. (2002). Filosofskyi entsyklopedychnyi slovnyk [Philosophical Encyclopedic Dictionary]. Kyiv: Abrys, 742 p. [in Ukrainian].

10. Tsokur, O. S.(1998). Katehoryia pedahohycheskoho soznanyia $\mathrm{v}$ teoryy y praktyke professyonalnoi podhotovky uchytelia [Category of pedagogical consciousness in the theory and practice of teacher training]. Doctor's thesis. Odessa, 269 p. [in Ukrainian].

11. Shvarp, N. V. (2011). Formuvannia profesiinoi samosvidomosti studentiv farmatsevtychnoho universytetu u protsesi fakhovoi pidhotovky [Formation of professional self-knowledge of students of the Pharmaceutical University in the process of professional training]. Extended abstract of candidate's thesis. Kharkiv: KhNPU im. H.S. Skovorody, 19 p. [in Ukrainian].

12. Shevchenko N.F. (2006). Formuvannia profesiinoi svidomosti praktychnykh psykholohiv u systemi vyshchoi osvity [Formation of professional consciousness of practical psychologists in the system of higher education]. Extended abstract of Doctor's thesis. Kyiv: In-t psykholohii im. H.S. Kostiuka APN Ukrainy 32 p. [in Ukrainian].

13. Bobovsky, R. P. (2016). Model structural components of pedagogical consciousness formation in future math teacher. "East West" Association for Advanced Studies and Higher Education. Vienna (Austria). pp. 286-289. [in English].

Стаття надійшла до редакції 16.11.2018

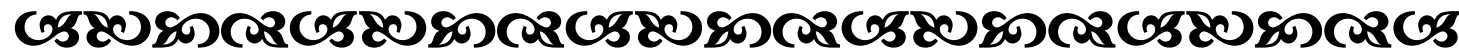

"Їм вручено чудову посаду, вище за яку ніпого не може бути під иим сонщем. Вічним законом нехай буде: вчити і вчитися всьому через приклади, повчання $і$ застосування на disi".

$$
\begin{aligned}
& \text { Я̆н Амос Коменський } \\
& \text { педагог }
\end{aligned}
$$

"Тізнання дитиною світу починається з пізнання людини, а людина відкривається перед дитиною в образі матері, батьқа і вчителя".

Василь Сухомлинський український педагог, публіиист

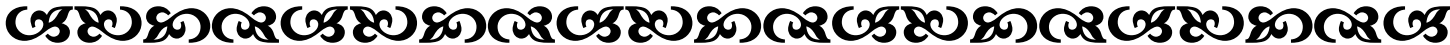

